\title{
Cinsiyetçilik Tartışmaları Çerçevesinde Mekânın Kullanımı: Uğurböceği Sevecen ve Salyangoz Tomurcuk Anaokulunda
}

\author{
Saadet SEVINÇ DOĞAN ${ }^{1 *}$
}

Öz

Erika Bartos tarafından yazılan çocuk kitabı cinsiyetçiliğin inşası açısından değerlendirilecektir. Kitabın ana karakterlerinin toplumsal cinsiyet rolleri, mekânın cinsiyeti özelinde tartışılacaktır. Bu tartışmanın temel amacı mekânın cinsiyet rollerini şekillendirmede önemli bir araç olduğunu göstermektir. Bu tartışmada bir başka amaç ise, cinsiyetçilik kodlarını çocuk edebiyatında görünür kılıp çözümlemektir.

Anahtar Kelimeler: Mekân, cinsiyetçilik, çocuk

\section{Usage of Place in the Context of Sexuality Discussions: Uğurböceği Sevecen and Salyangoz Tomurcuk in Kindergarten}

\begin{abstract}
The children's book written by Erika Bartos will be evaluated in terms of the construction of sexism. The gender roles of the main characters of the book will be discussed specifically in the gender of the place. The main purpose of this discussion show us that space is an important tool in shaping gender roles. Another aim in this discussion is to make the codes of sexism visible on children's literature.
\end{abstract}

Keywords: Place, sexism, child.

${ }^{1}$ Kocaeli Üniversitesi, Basın ve Halkla İlişkiler Müdürlüğü, Ankara Üniversitesi İletişim Fakültesi Gazetecilik Bölümü, Doktora Öğrencisi,

*ilgili yazar / Corresponding author: saadetsevinc@gmail.com

Gönderim Tarihi: 15.12.2016

Kabul Tarihi: 15.05.2017 


\section{GíRiş}

İçinde yaşanılan kültür farklı bileşenleri ile bireyin davranışlarında belirleyicilik gösteriyorsa, farkında olalım veya olmayalım yaşam tarzlarımız, dışımızdaki pratikler üzerinden kuruluyor demektir. Bu pratikler maddi pratikleri de barındırdığı ve bu çalışma özelinde mekân ve mekâna toplumsal cinsiyetin inşası açısından bakacağımız için cinsiyet, toplumsal cinsiyet ve feminizm üzerine düşünmek önceliklidir. Bu açıklamaların ardından yazıya konu olan kitap niteliksel analizle ele alınacaktır. Metin analizi ile değerlendirmeye alınacak olan kitapta cinsiyetçiliğin nasıl inşa edildiğini görmek için tüm unsurlar değerlendirilecektir. Bu bağlamda çocukların kıyafetleri, anaokulunda kullanılan renkler, oyuncaklar ve son olarak öğretmenin durumu da incelenecektir. Belirlenen kategoriler detaylı olarak cinsiyetçiliği inşa sürecinde üstlendikleri rol ile değerlendirilecektir. Ancak bu analizin yapılabilmesi için kavramsal olarak feminist teoriler ve cinsiyetçilik ile ilgili tartışmalara da değinilecektir.

Konuyla ilgili farklı bakış açıları mevcuttur. Örneğin bir tanesi biyolojik özelliğe vurgu yaparken, yani kadın ya da erkek olarak doğmamızla ilgiliyken, diğeri toplum tarafından belirlenen ve beklenen rol ve kalıpları işaret etmektedir. Catharine A. Mackinnon'a göre bağımsız olarak biyolojik farklılıklar üzerine kurulmamış bir sistemde her ikisi de hem toplumsal hem politiktir (MacKinnon, 2003, s. 11).

Bu çalışmada daha ziyade üzerinde durulacak olan kavram toplumsal cinsiyet ve bu anlamda kullanılan cinsiyetçilik olarak belirlenmiştir. Biyolojik özelliklerin dışında tarihsel, kültürel ve sosyolojik olarak belirlenen toplumsal cinsiyet kavramı, cinsiyetten kaynaklı eşitsizliklerin oluşturulduğu alan olarak ifade edilebilir. Cinsiyetçilik ayrımcılığın yapıldığını da ifade etmektedir. Konuyla ilgili "Mill'in analizi cinsiyet ayrımının akıl dışı, dolayısıyla adaletsiz olduğu üzerine kurulmuştur (MacKinnon, 2003, s. 63)". Toplumsal cinsiyet kavramını toplumsal, kültürel, tarihsel süreçlerle birarada irdelerken ortaya çıkan eşitsizlik karşısında iktidarın duruşu ve tavrı da ayrıca önem taşımaktadır. Genel anlamıyla iktidarın beslediği toplumsal cinsiyet ile ilgili Serpil Çakır "Toplumsal cinsiyet olarak kavramsallaştırılan, kadın ve erkek olma hallerinin üzerinde yaşandığı zeminde, sadece cinsler arasındaki iktidar ve otorite ilişkileri anlaşılmakla kalmaz, devlet ve birey arasındaki ilişki de somut olarak açığa çıkarılabilir (Çakır, 2009, s. 79)" diyerek önemli bir vurgu yapmaktadır. Toplumsal cinsiyet kavramının ne olduğu üzerine bir başka açıklama da Aksu Bora'dan gelmektedir. Benzer argümanlar etrafında yapılan tanımlamada Bora toplumsal cinsiyet kavramının son derece karmaşık toplumsal ilişkiler ağı içinde kurulduğunu ve bu çerçevede sadece biyolojik farklılıkla yapılacak açıklamaların yetersizliğini belirtir. Önemli bir noktayı gösteren Bora açıklamasında "Kavramın arkasında yatan fikir, cinsiyetin toplumsal bir "inşa" olduğudur. Kadınlık ve erkeklik, doğuştan getirilen biyolojik özelliklerden çok, toplumsal birer kurgu olarak ele alınır (Bora, 2010, s. 22)" ifadelerine yer vermektedir. Çoklu bileşenleri ile kavram, içinde bulunduğumuz ortamı anlamlandırmak için daha farklı alan çalışmalarını da gerektirmektedir. Toplumsal cinsiyet ile ilgili kısa ancak oldukça net bir tanımlamada bulunan Joan W. Scott'a göre "Toplumsal cinsiyet iktidar ilişkilerini belirgin kılmanın asli yoludur (W. Scott, 2007, s. 43)." Toplumsal cinsiyet kavramının ne olduğuna dair tanımlara bakarken bir yandan da kimi feminist kuramcıların doğa-kültür karşıtlığı üzerinden cinsiyet ve toplumsal cinsiyet kavramlarına yaklaştıklarını görmekteyiz. Judith Butler de bu konuda yapılan çalışmalar üzerinden şunları söylemektedir "Kimi feminist kuramcılar cinsiyet-toplumsal cinsiyet ayrımını desteklemek ve açıklamak için sorunsal doğa-kültür ayrımı da dâhil olmak üzere Levi-Strauss'un yapısalcı antropolojisini sahiplendiler. Bu konuma göre doğal veya 
biyolojik bir dişi vardır, sonradan toplumsal olarak ikincil konumdaki "kadın"a dönüşür. Yani sonuçta "cinsiyet" doğaya ya da "çiğ/ham" a tekabül ederken toplumsal cinsiyet kültüre ya da "pişmiş"e tekabül eder (Butler, 2008, s. 93)." Bu tanımlamaya eleştirel yaklaşan Butler, kültürün doğaya anlam dayattığını belirtir ve hiyerarşik bir düzenin desteklenip bir tür ötekileştirmenin yaratıldığını söyler (Butler, 2008, s. 94). Bu tartışmalardan günümüze Moira Gatens'ın da bir röportajında belirttiği gibi artık toplumsal cinsiyet denildiğinde bir bütün olarak feminizm, kadın sorunları vb. diğer alana dair tartışmalar anlaşılmaktadır. Cinsiyet ve toplumsal cinsiyet arasındaki ayrımla ilgili 1970'lerdeki tartışmaların bugün de devam ettiğini belirten Gatens cinsiyet kelimesinin kullanıldığı yerlerde insanların zihinlerinde sadece cinsel münasebetin geldiğini belirtmektedir (Gatens, 2004, s. 213-214).

\section{CINSIYYTÇILIK VE FEMINIST TEORILER}

Cinsiyetçilik meselesine feminizm açısından farklı yaklaşımlar da vardır. Bunlardan liberal feminizme göre "cinsiyet eşitsizliği sorunu, yasa ve gelenekler aracılığıyla, insanların potansiyellerini kısıtlayan iki rastgele ve mantıksız toplumsal cinsiyet rolünü üstlenmeye zorlanmalarıdır. Radikal feministler içinse cinsiyet, toplumsal iktidarın sistematik olarak bölünmesi, insanların toplumsal cinsiyetlerinden soyutlanamayan bir toplumsal prensiptir; kadınların zararına, zorla kabul ettirilmiştir çünkü güçlü olanın, yani erkeklerin çıkarına hizmet eder (MacKinnon, 2003, s. 60-61)". Kadın olmak ve dünyanın neresinde olursa olsun kadın olarak yaşama dâhil olmak beraberinde pek çok eşitsizliği de getirmektedir. Kadınların kendi yaşamlarına dair yapılan eşitsizliği fark etmeleri çok uzun yıllar öncesine dayanmakla birlikte bu alanda yapılan karşı duruşlar acımasız cezalarla karşılanmıştır. Bunlardan sadece birini örnek verecek olursak, 1791 tarihinde Kadın Hakları adlı bir el broşürü yayınlayan Olympe Gouges'in giyotinle idam edilmesi (Donovan, 2007, s. 15) bile tarihsel süreçte karşılaşılan olayları düşünmek için yeterlidir. Bu engelleme çabaları bugün de devam etmektedir. Farklı mekân ve zamanlarda farklı şekil ve dozlarda da olsa bu mücadele alanı hala canlılığını korumaktadır. Bu değişimi sosyal değişimlere paralel olarak değerlendiren Alexander $\mathrm{R}$. Cuthbert de endüstrileşme ve sonrası süreçte zaman zaman kadına yönelik avantajı kısımlar artıyor gibi görünse de erkeklerin devlet, askeriye, iş yaşamı, eğitim ve diğer sosyal gelişmelerdeki etki ve baskısı belirgin ve fazladır (R. Cuthbert, 2006, s. 130), diyerek aslında sürecin çok da kadınlar lehine dönmediğini göstermektedir. Günümüzdeki cinsiyet alanındaki aktivizme ve toplumsal cinsiyet haklarının korunma çabasına karşı oluşan dirençleri irdeleyen Deniz Kandiyoti de bu noktaları şu şekilde sıralamaktadır: "Bunlar; hükümetlerin kadın hakları platformlarına el koymaları ile bunların apolitikleştirilmesi (bunun en çarpıcı örnekleri baskı ve antidemokratik rejimlerdir), giderek derinleşen küresel neo-liberal politikalar ve bu politikaların haklar gündemi üzerindeki etkileri ve kadın haklarının 11 Eylül sonrası inşa edilen "teröre karşı savaş" çerçevesinde jeopolitik amaçlara yönelik biçimde araçsallaştırılmasıdır (Kandiyoti, 2011, s. 51-52)". Geçmişten günümüze devam eden bu değersizleştirme çabalarına karşı duruşlar süreklilik arz ederek olumlu bazı sorgulamalara neden olmuştur. Feminist çalışmalar çerçevesinde yapılan sorgulamalar buna örnek gösterilebilir. H. Leslie Steeves'ın da belirttiği gibi "Feminist teoriler kadınların toplumdaki neredeyse evrensel değersizleştiriminin kökenlerini ve bunun sürüp giden mahiyetini anlamayı amaçlar. 'Feminist' terimi, kadınların erkeklerle ilişkili olarak geleneksel değersizleştiriminin gerçekliğinin, bu ilişkinin değiştirilmeye intiyacı olduğu varsayımıyla teorik açıdan kabul edilmesini ima eder (Steeves, 1999, s. 129)."

Feminist teori ve üzerinde durduğu konuları temelde üç noktada birleştiren Nira-Yuval Daris'e göre tüm literatür bu üç soru etrafında dönmektedir. Buna göre kadınların neden baskı altında olduğu, kadın ve erkek arasındaki farklılıkların ontolojik temelleri ve bu temellerin sosyolojik mi biyolojik mi, yoksa ikisinin birleşimi ile mi oluştuğu sorusu ile kadın ve erkek arasındaki farklılıkların toplumsal cinsiyet ilişkilerine genelleştirimi üzerinedir (Yuval Davis, 2003, s. 24-25). Bu ifadelerden de anlaşılacağı gibi farklı bileşenleri olmakla birlikte 
toplumsal cinsiyet kavramı beraberinde kalıp yargıları ve toplumsal rolleri de getirmektedir. Feminist teori ve buna paralel politikayı etkin veya gerekli kılan da kadınların temelde maruz kaldıkları eşitsizliklerden oluşmaktadır. Soruları, tanımlamaları ile feminizm kadınlar arasında kurulur ve Aksu Bora'nın da ifade ettiği gibi "negatif ortaklık" (Bora, 2010, s. 48-49) temelinde kendine politika üretir ve bu alanda sorunu görünür kılma çabasıdır. Gerek feminist politika gerekse cinsiyetçilik üzerine yapılan pek çok çalışma da gösterir ki inşa ile tarif edilen cinsiyetçilik sürecinde olumlu ve olumsuz kavramlar gün içindeki farklı mekân ve zamanlarda kendini tekrar eder. Bu tekrar içinde Gül Özyeğin'in de belirttiği gibi "Kadın ve erkeklik çocuklukta içine girilen sabit kalıplar değil; hem tahayyülde hem de gündelik yaşamdaki karşılaşmalarda sürekli gözden geçirilen, sınanan, yeniden ele alınan şeyler" (Özyeğin, 2010, s. 12) olarak yer alır. Tam da Özyeğin'in de belirttiği noktadan hareketle toplumsal roller ve kalıpların da aktarılarak devamlıık kazandığını ve benzer davranışları inşa ettiğini belirtebiliriz. Cinsiyetçilik ile ilgili yukarıda belirtilen radikal ve liberallerin görüşlerinin yanında yine Catharine A. Mackinnon'dan aktaracak olursak; "Liberal feminizm cinsiyetçiliği öncelikle bir yanılsama, kurtulunması gereken bir efsane, düzeltilmesi gereken bir aksaklık gibi görürken, feminizm, eril bakış açısını eril iktidarın yalnızca aldatıcı bir ürünü olarak değil, dünyayı kendi suretinde, kendi arzuları doğrultusunda yaratmasını sağlayan temeli olarak değerlendirir (MacKinnon, 2003, s. 61)".

\subsection{Toplumsal cinsiyet ve mekanın kullanımı}

Toplumsal cinsiyet konusu tartışılırken bir başka öne çıkan konu da kamusal ve özel ayrımıdır. Çok genel ifadeyle kadının ait olduğu yerler daha özel, erkeğinki ise kamusal alana ait gösterilir. Bu da bir diğer taraftan erkeğin söz sahibi olduğu alanlar ile kadına bırakılan alanlar gibi düşünülebilir. Aksu Bora'nın kamusal alan ve özel alan ile ilgili karşılaştırması kadına biçilen rol açısından da önemlidir. Bora'ya göre: “...özel alan diğerkamlığın, vericiliğin, duyguların, kabullenilmiş bir eşitsizliğin, informel ilişkilerin; kamu alanı ise adaletin, rasyonalitenin, sorumluluk ve hesap vermenin, eşitliğin, formel ilişkilerin alanı. İktidar odağı birinde baba, ötekinde devlet, birinde "doğal" yasalar geçerli, ötekinde insanların yaptığı yasalar (Bora, 2004, s. 529)". Kadının ve erkeğin alanları şeklinde belirtildiğinde mekânın cinsiyetlendirilmesinde ortaya çıkan eşitsizliği yok edecek farklı mücadele alanları da belirmektedir. Mekânın cinsiyeti denilen kavram tam da burada yerini bulmaktadır. Eser Köker kamusal yaşamın hemen her alanında kadınların özel yaşamlarıyla ilgilenildiğini şu sözlerle belirtmektedir; "Çok bilineni tekrar edecek olursam, ulusal meclislerden sendikalara, işyerlerinden meslek odalarına kadar kamusal yaşamın her hücresine sinmiş olan cinsiyetçilik, kadınların özel yaşamlarıyla ilişkilidir (Köker, 2004, s. 543)". Kamusal ve özel ayrımında evin dişil olarak kabul edilip özel sayılması ve kadına ait alan şeklinde ifade edilmesi ve tüm bu ayrımlar da toplumsal cinsiyet eşitsizliğini pekiş̧irici açıklamalardır. Bu konuda "Evi 'özel' olarak kabul etmek, aileyi, hem evi hem de pazarı bölen cinsiyete dayalı bir iktidar bölüşümüyle ayırt edilen bir bütünlük içinde ele almak yerine kadının ezilmesini özelleştirmek ve kadının statüsünü kamusal alanın türevi olarak incelenmesi gereken bir ev içi ilişkiler meselesi haline getirmek demektir (MacKinnon, 2003, s. 55)" diyen Catharine A. Mackinnon'un sözleri dikkate değerdir. Cinsiyetlendirilmiş mekan kavramına ev üzerinden yaklaşan bir başka araştırmacı da Paula Townsend'dır. Townsend'in "Gendered Space?" adlı makalesinde ev kavramının 3 temel özelliği olduğu; bunların da kültürel ve geleneksel değerlerin üretimi, özel alan, güvenlik ve yaratıcılık ile kendini ifade etme ortamı şeklinde sıralandığı belirtilir. Ev nedir diye sorduğunda ise bunun sadece bir bölge olmasının ötesinde çetrefilli ve farklı bileşenleri olan bir mekân olduğunu belirtir. Evin feministlere göre cinsiyetçiliğin baskın olduğu, kadınların sömürüldüğü mekân olduğu, liberallere göre kişisel özgürlüğün kalesi ve devlet otoritesinden ayrılmış özerk alan olduğu, sosyalistlere göre ise kollektif yaşam önündeki engel olduğu ve kapitalist sosyal ilişkilerin yeniden üretildiği alan olduğunu açıklamasını Sounders'den alıntılayan Townsend günümüz toplumlarında ev kavramının neye tekabül ettiği üzerinde de durmaktadır. Medya tarafından şekillendirilen bir kavram olduğu vurgusunun yapıldığı ev için bazen aile-ev içiçeliğinden de bahsedilir. 
Çalışmanın önemli bir yönü de evin alanlarının kadın ve erkekler tarafından nasıl kullanılı̆̆ıdır. Buna göre erkekler garaj, sığınak, bahçe alanlarını kendilerine ait görürken kadınlar yatak odası ve mutfakla yoğunluklu olarak özdeşleşirler. Yine önemli bir vurguyu Graham'dan yapan Townsend kadının evde olmayı tercih etmesinin, yani dışarıda vakit geçirmek yerine evde kalmayı istemesinin ideolojik bir tercih olduğu ve kültürel olarak aktarımasının yanında bunun cinsiyetçiliği pekiştirici ve üretici bir tercih olduğunu belirtilmektedir. Yine bir başka konu da ev dekorasyonu ile ilgili işlerde kadınların başrolde olmak istemelerini de sınırlı da olsa özgürlük ve kendilerini ifade etme aracı olarak görmektedirler. Güvenlik kavramı da ev konusuyla ilgili bir diğer göze çarpan etkendir (Townsend). Dolayısıyla hayatın hemen her alanında olduğu gibi kadınla özdeşleştirilen ev ile ilgili çalışmalar da cinsiyetçilik üzerinden oldukça aydınlatıcı veriler sağlamaktadır. Kadınların neden evde oldukları veya sınırlandırılmış bir tercih olarak bu seçeneği seçtikleri üzerinden bir başka bakış açısı ise Simone de Beauvour'a göre şöyledir; "Onlar yalnızca grevlerden, işsizlikten, yoksulluktan değil, aynı zamanda başkaldırmanın günah olmasından korkmaktaydılar. Öyle de böyle de boyun eğeceklerine göre, alışılmışı serüvene yeğ tutmalarını anlamak kolaylaşıyor; o minicik mutluluklarını sokaklarda değil, ancak evlerde kurabiliyorlar çünkü (Simone, 1993, s. 13). Kadının konumu ve kamusal alan ile özel alan kavramlarına kent ile ilgili bölümde daha detaylı olarak girilecektir. Kamusal alanın ne olduğu ve günümüzde bu kavramların nasıl değişip dönüştüğü üzerine de tartışmalar kadının içinde bulunduğu durumu anlamak açısından gereklidir. Tıpkı değişen ve dönüşen kavramlar gibi yaşamın tüm alanlarında ve önemsiz gibi görülen hemen her ayrıntıda cinsiyetçilik üzerinden sorgusuz kabullendiğimiz söylemler kadar davranışlara da rastlamaktayız. Zihniyet örüntülerimizin somut nesnelere dönüşmesi ile ortaya çıkarılan hizmetler veya kullanılan araçlar dahi bu kategoride değerlendirilebilir. Ne olduğunun, neye uygun olduğunun, neye ne kadar hakkı olduğunun belirlenmişliğindeki kadın daha ilk yaşlarında kendisine sunulan ve ebeveynlerin tercihleriyle (bu tercihler de onlara öğretilenlerdir ve kültürel geçmişin izleriyle beslenmiştir) eline verilen oyuncaklardaki ayrıcalıklarla algılamaya başlar hayatı. $\mathrm{Bu}$ belirlenmişlik halinde sırasıyla renkler, algılar, oyunlar, davranış şekilleri derken bilinçaltı haritaları oluşturulur. En kısa haliyle "toplumsallaşma" adı verilen bu süreçte kendisinden önce devredilen eril bakışı öğrenen ve bununla yoğrulan küçük bedenler bu sürekliliği gündelik hayatın diğer saflarında da, eğitim gibi, kolayca sürdürebilmektedir. Bu konuda Kamla Bhasin de '...her kültürün kızları ve oğlanları değerlendirme yöntemi vardır ve onlara farklı roller, tepkiler, nitelikler yükler. Doğumlarından itibaren kızlara ve oğlanlara tüm bu sosyal ve kültürel algı ve davranışların "paket halinde yüklenmesi" aslında, "toplumsal cinsiyetin öğretilmesi ve benimsetilmesi"dir; der (Bhasin, 2003, s. 1-2). Toplumsal cinsiyetin öğretilmesi, aktarılması veya benimsetilmesi denilen süreçte simgeler, semboller gibi benzer şeyler devreye girmektedir. Bir şeyin eril olması veya dişil olarak kabul edilmesi de bu sosyalizasyon süreçleriyle paralel ilerlemektedir. Yaşamın tüm alanlarını kaplayan ve tüm davranışlarımızda etkisi olan bu sosyalleşme süreçleri hayatı ve kendimizi algılamamızı da etkilemektedir. Bu süreçte önemli bir başka noktası ise din konusudur. Tam da Beauvoir'in belirttiği gibi din genel anlamda erkeği üstün görmekte ve bunu toplum tarafından da sabitlemektedir. Beauvoir "Tıpkı halk gibi ve aynı nedenlerden ötürü, kadınlar için de bir din gereklidir: bir cinsi, bir sınıfı içkinliğe mahkum ettiniz mi, ona, aşkınlığa benzer bir şey vermek zorundasınızdır. Erkeğin, ortaya attığı yasaları bir Tanrı'nın sırtına yüklemekte büyük çıkarı vardır: hele kadın üzerinde yüce bir yetke kurduğuna göre, bu yetkenin kendisine yüce bir varlıktan gelmesi son derece iyidir. Gerçi hemen bütün dinlerde öyledir ya, özellikle Yahudilik, Müslümanlık ve Hıristiyanlık'ta, erkek, Tanrı'dan gelme bir hakla efendidir: Tanrı korkusu, ezilen kadındaki her türlü başkaldırma isteğini daha çekirdek halindeyken yok edecektir (Simone, 1993, s. 34)" diyerek, içine doğulan kültürün önemli bir parçası olan din karşısında da kadının tanımlanışının dezavantajı olduğunu göstermektedir. Ön kabuller ve sosyalleşmeyle devam edilen süreçte kadının önce kendisinin ne olduğunu anlaması ve genel kabulün dışına çıkma çabasında olması gerekmektedir. Çünkü din gibi diğer faktörler de kadının konumu üzerinde düşünülmesi gereken unsurlardır. İnsanların kendilerini ve hayatı algılayışlarını sosyalleşme veya diğer faktörler aracılığıyla tanımladığını farklı bir 
şekilde ifade eden Carol Delaney sözleri ile önemli bir vurguda bulunmaktadır. Kitabında Boas'tan alıntılama yapan Delaney onun "gören göz, geleneğin aracıdır" sözünden yola çıkarak bu sözün doğru kabul edilmesi halinde yapılması gerekeninin odak noktamızın yeniden ayarlanması gerektiğidir (Delaney, 2012, s. 49) diyerek iyi bir yol gösterendir. Çünkü gelenekler de davranışlarımızı diğer faktörler gibi büyük ölçüde etkilemektedir. Dinin insanların önkabulleri ve inşa edilmişlikleri üzerine etkisi kadar önemli bir diğer etken de dildir. Dilbilimcilerin alanına girmekle birlikte bu çalışma özelinde kısaca değineceğimiz konu dilin de cinsiyetçilik konusundaki taraflı yapılandırıışıdır. En basit haliyle insanı tanımlamak için kullanılan "insanoğlu" terimi veya İngilizcede insan kelimesinin "human" olarak kullanımı bile cinsiyetçilik açısından konunun ele alınabilirliğini göstermektedir. Dilin nötr olmadığı üzerine görüş belirten Judith Butler'e göre; "İnsan çeşitli üslupları kullanabilir elbette, fakat hangilerini kullanabileceği tümüyle kendi seçimine kalmamıştır. Dahası, ne gramer ne de üslup siyaseten nötrdür. İdrak edilebilecek konuşmayı idare eden kuralları öğrenmek normalleştirilmiş dile alıştırılmaktır, kurallara uymamanın cezası da idare edilebilirliğini yitirmektir (Butler, 2008, s. 24)". Bir taraftan kadının kendisini nasıl algıladığı, diğer taraftan kendi dışındakilerin onu nasıl algıladığı önemlidir. Farklı bakış açıları farklı şekillerde kadını tarif etmektedir. Bazılarına göre erkeğin ötekisi iken bazılarına göre daha farklı şekillerde tanımlanmaktadır. Örneğin, "Sosyalist feministler genellikle (her zaman ifade etmeseler de) kadınlar ve proleterya arasında bir benzerlik olduğunu kabul ederek; benzer biçimde erkek ve yönetici grup çıkarlarına hizmet eden "yanlış bilinç" ya da "erkekle özdeşleşen" ideolojileri açığa çıkarma sürecinde, kendi ezilmişlik durumlarının doğru bir bilincini geliştirme yönünde kadınları teşvik ederler (Donovan, 2007, s. 133)". Feminizmin tarihi ve önemli feministler ile ilgili bilgilerin yer aldığı Margaret Walters'in kitabında da Adem ve Havva figürlerinden ilk feminist hareketlere, kadın hakları savunucularından kadınların oy kullanma hakkı için mücadele eden süfrajetlere ve 20. yüzyıl feminizminden ikinci dalga feminizmine alanda önemli kişilerin hayat hikayelerinden alıntılar yapılmıştır. Çalışmanın kadın araştırmaları için önemli olan ve geniş bir perspektif oluşmasını sağlayan yanı ise din gibi konuşulmasının ve tartışımasının dahi tabu olduğu kavramlardan edebiyata, siyasetten günümüz dünyasına kadar farklı alanlarda kadın sorunları üzerine nelerin konuşulduğuna dair bir yol çizmesidir. Bu bağlamda eril olanın ne olduğu, kadına dayatılanın ne olduğu ve neden dayatılığı, kadın ve erkek gibi ayrımların yapılmasının toplumsal izdüşümleri de konuyu kapsamlı bir şekilde anlayabilmek için ele alınmalıdır. Bu aynı zamanda bir kendini anlama çabasının gerekliliğidir. Bu çaba ile etrafına ve kendisine sunulana da daha farkındalıkla bakan kadının kent yaşamındaki yeri ve katıımı konusunda "eşitliği" yaratma konusundaki çabaları veya görmezden gelinen konuları, normalleştirilen bakış açılarını anlayabilmek önemlidir.

İşte tam da bu noktada okul öncesi bir kitapta mekân üzerinden yeniden inşa edilen cinsiyetçilik konusu önemli ve gereklidir. Farklı türden bir okumanın bu alanda dayatılan rolleri görmek ve olası ayrımcılığı dağıtmak anlamında katkısı olacaktır. Gördüğü, duyduğu, hissettiği, dokunduğu ile mekânda yaratılan rollerin kızlar ve erkekler açısından toplumsal cinsiyeti pekiştirici ve yeniden inşa edici rolü metin analizi ile ele alınacaktır. Böylece mekânda kadına dayatılan ve ondan beklenenler daha net görülecektir.

Eril sisteme göre inşa edilen ve kadın erkek ayrımcıığını daha da çok belirginleştirip cinsiyetçiliği yeniden inşa eden bu mekânlara içinde yaşadığımız kentte de çokça örnek bulmak mümkündür.

\subsection{Mekanda kadın}

Kadının mekândaki hareketi, iş yaşamı, mekanı kullanımı ve mekanın tasarlanması toplumsal cinsiyet eşitsizliğini genel anlamda pekiştirmektedir. Konuyla ilgili Ayten Alkan'ın "yalnızca liberal ve neo-liberal ekonomistler değil, Marksist ve Neo-Marksist ekonomistlerin de kentin kullanımı ve ekonomi üzerinde önemli etkilere sahip olmasına karşın kadınların ev içinde harcadıkları emeği göz ardı ederler. Sonuç olarak, kentsel toplumsal ekonomik yaşamı 
anlamada genel eğilim, hane içi ilişkiler ve toplumsal cinsiyet unsurunun dışlanması yönündedir (Alkan, 2005, s. 45)" şeklindeki görüşleri de bu konuya dikkat çekmektedir.

Kent içinde kadının sosyal hayata katılımının önünde duran ve görmezden gelinen pek çok detay pratikte ciddi sorunlar oluşturabilmekte ve bunun da arkasında yerel yönetimlerin ilgisiz tavırları ile kendinin/talep edeceğinin farkında olmayan kadınların olduğunu görmek gerekmektedir. Alkan'ın çalışması yine bu anlamda ince bir vurgu yapmakta ve belirli bir saatten sonra kent yaşamının sadece erkeklere ayrılmasının sessiz bir anlaşma ile sağlandığını hatırlatmaktadır. "Aynı kentin aynı sokaklarında yürüyen kadınlarla erkekler, özellikle belli bir saatten sonra, çok farklı duygular yaşarlar. Kadınlara doğrudan olmasa da dolaylı olarak yasaklanmış ya da girişi belli kurallara bağlanmış 'ortak' mekânlar vardır (Alkan, 2005, s. 54)". Çoğu durumda farkında olunmayan ve gündelik hayatın içinde göze çarpmayan bu sessiz sözleşmelerle kadınlar güvenlik başta olmak üzere pek çok endişe ile kent yaşamına eşit şekilde dâhil olamamaktadır. Eşit şekilde dâhil olamama da eşitsizliği beraberinde getirmekte ve gündelik hayat pratiklerinde bu durum daha da derinleşmektedir. Yıldız Temürkan da bu eşitsizliği şu şekilde özetlemektedir: "Kent, toplumsal cinsiyeti eşitsizliğin yaşandığı esas alan olarak ön plana çıkmaya başladı. Çünkü kentler, cinsiyetlendirilmiş norm ve kimliklerin üretim, tüketim ve yeniden üretim sürecinde kilit mekanlar işlevi görür (Temürken, 2011, s. 39)". Farklı mekan ve zamanlarda da olsa hemen her kadının bir şekliyle maruz kaldığı eşitsizlikler ve mekanı erkeklerle aynı şekilde kullanamama durumunu özetleyen Catherine Redfern ve Kristin Aune konuya hak meselesi üzerinden yaklaşırlar. İkili çalışmalarında cadde ve sokaklarda güvenle hareket etmenin temel bir hak olduğu ve bu alanların kamusal alanlar olduğunu belirtmektedirler (Redfern ve Aune, 2012, s. 119-120) ve bu önemli bir vurgudur. Ancak burada dikkat edilmesi gereken temel nokta, bu konuda çoğu araştırmacının da belirttiği gibi kente katıımda kadının gereksinimleri olarak ifade edilebileceklerin farkında olmamasıdır. Bu anlamda mekân ve mekânın kadının kullanımına imkan sağlayacak çalışmalarda bu nokta göz önünde bulundurularak öncelikle Alkan'ın da ifade ettiği üzere "Toplumsal cinsiyet gereksinimlerine duyarlı uygulamaların, gereksinimlerin açığa çıkıp tanımlanmasını olanaklı kılacak ortam ve düzenekleri yaratması beklenir (Alkan, 2005, s. 61)". Bu ifadesini cinsiyet körü diye tanımladığı yerel politikalar için de kullanan Alkan'ın dikkat çektiği nokta kadınların mekânı tüketmelerinde daha eşitlikçi imkanlar yaratılması için küçük ipuçları olarak değerlendirilebilir. Oldukça detaylı ve toplumun farklı kesim ve kurumlarını kapsayan böylesi bir farkındalık çalışmasında yerel yönetimlere büyük görev düşmekle birlikte ildeki üniversiteler ve sivil toplum örgütleri de benzer sorumlulukla hareket etmelidir (Tekeli, 2010, s. 31).

Tam da bu bakış açısından hareketle anaokulu içinde kızlar ve erkekler için ayrı odaların düzenlenmesi ve bu odaların renk, oyuncaklar ve dekorasyon açısından incelenmesi mekânın cinsiyet eşitsizliğini nasıl görünür kıldığını göstermek bakımından önemlidir.

Yukarıda da belirtildiği gibi toplumsal cinsiyet eşitsizliğinde bireyin içine doğduğu aile kadar, toplumsal yapı, kültürel çevre de önemli rol oynamaktadır. Aileden sonra özellikle çocukların ilk sosyalleşme alanı olan okullar cinsiyetçilik kavramına yaklaşımları özelinde oldukça büyük bir paya sahiptir. Bu bağlamda bu yazıya da konu olan okul öncesi kitabı Uğurböceği Sevecen ile Salyangoz Tomurcuk Anaokulu'nda kitabında erkekler ve kızların farklı oyuncaklarla oynamasına ve Uğurböceği Sevecen'in araba, yani erkek dünyasına ait bir oyuncak ile oynamasına izin verilmemektedir. Ayrıca yine onların arasında olması da istenmemektedir. Son derece açık bir şekilde cinsiyetçiliğin yaşandığı mekân tüm verileriyle incelendiğinde aynı tablo ortaya çıkmaktadır. Mekân olarak anaokulu kızların ve erkeklerin oynayacağı oyunları ve oyun odalarının ayrışmasıyla da oynayacakları mekânı da belirlemektedir. Dolayısıyla verili olanlar bizlere aynı zamanda neyin kızlar ve erkekler için uygun görüldüğünü de resmetmektedir. Metin analizinin yapıldığı çalışmada renkler, anaokulundaki oyun odalarının dekorasyonu, oyuncaklar, çocuklar arasında geçen diyaloglar ve öğretmenin konumu da ele alınmıştır. 


\section{UĞURBÖCEĞi SEVECEN ILE SALYANGOZ TOMURCUK}

Erika Bartos tarafından kaleme alınan Uğurböceği Sevecen ve Salyangoz Tomurcuk Yapı Kredi Yayınları tarafından ilk baskısını 2013 yılında yapmıştır. Oldukça geniş bir serinin bir bölümü olan "Uğurböceği Sevecen ve Salyangoz Tomurcuk Anaokulunda" kitabında iki arkadaş okula gitmektedir. Başlangıç için beraberce hareket eden çocuklar oyun oynama kısmında cinsiyetlendirilmiş oyuncaklarla ayrılmış mekânlarda erkek ve kızlar dünyasının kendilerinden bekledikleri rolleri gerçekleştirmektedirler. Yalnız Uğurböceği Sevecen elinde bir araba ile bir ara erkeklerin oyun alanına gelerek onlarla oynamak istediğini söyler. Ancak bu talebi sert bir şekilde reddedilir. Kendilerini oturduğu yerden izleyen öğretmenleri de tünel kazan, arabalarıyla oynayan, yollar yapan ve Uğurböceği'ni aralarına almayan öğrencilerine hiçbir müdahalede bulunmamaktadır. Serbest zaman olarak tanımlanan bu zamanda erkeklerle beraber oynamak isteyen Uğurböceği Sevecen'e "Dalga geçme, Sevecen! O işe yaramaz arabayla mı oynamak istiyorsun?" demektedirler. Ayrıca "Zaten araba oyunu kızlara göre değildir!" diye de sözlerini cinsiyetçi bir ifade ile sonlandırmaktadırlar. Ağlayarak yanlarından ayrılan Sevecen bu sefer kızlar için ayrılan mekânda kendine yer alır. Burada tam da eril iktidarın kendisinden beklenen rollerle donatılmış oyuncaklar ve dekor ile karşılaşırız. Dekor ve oyuncaklar kısmı ayrı ayrı ele alınacağı için bu kısmı sonraya bırakarak, okur olarak sadece mekânın cinsiyetçiliği söze gerek duymadan da nasıl inşa ettiğine tanık oluyoruz diyebiliriz.

Bir şekilde arkadaşlarıyla anlaşmazlığa düşen Tomurcuk bu sefer erkek arkadaşlarına küser ve soluğu Sevecen'in yanında alır. Sevecen önce kendisine sarfedilen sözler gibi karşılar Tomurcuk'u ama sonra tavrını değiştirir. "Hayır, oynayamazsın, bu oyun kızlara göre" diyen Sevecen sonrasında elinde bebekle bekleyen Tomurcuk'u kabul eder oyunlarına ve mekânlarına. Tomurcuk elindeki bebeği göstererek "Bak bir bebek getirdim, bu kıvırcık saçlı bebeği. Ben de sizinle oynamak istiyorum!" diye direten Tomurcuk kızların alanına onlara ait kabul edilen bir oyuncak ile dâhil olur. Sevecen, Tomurcuk'u sonra onun da araba ile oynamasına izin vermesi şartıyla kabul eder. Kısaca kitapta en belirgin diyaloglar bunlardan oluşuyor. Şimdi daha yakından bakarsak cinsiyetçiliğin diğer unsurlarla birlikte nasıl yeniden inşa edildiğini daha net görebiliriz.

\section{1. Çocukların kıyafetleri}

Kitapta yer alan kız çocukları ve kadın öğretmen elbise giymiştir. Bunların canlı olarak türü fark etmeksizin sadece cinsiyetleri giydikleri elbise ile belirginleştirilmiştir. Erkek olarak temsil edilen diğer canlılar da pantolon giymişlerdir. Kızların hepsinin saçları uzundur. Kısa saçlı bir tane bile kız yoktur resimlerde. Bununla birlikte kızların oyuncak olarak kullandıkları tüm bebekler de kızdır ve onların da saçları uzundur. Bir anlamda bir konu tartışmaya yer bırakmaksızın kızların/kadınların elbiseli ve uzun saçlı olması gereğini vurgular niteliktedir. Kız çocuklarının kıyafetleri ağırlıklı olarak kırmızı, mor, yeşildir. Bu istinanın dışında bir tane açık mavi renkli elbise giymiş bir kız bulunmaktadır.

Erkeklerde ise pantolon ve üst yer almakta ve hepsi kısa saçlı gösterilmektedir. Kahve ve tonları ile gri ve siyahı da gördüğümüz kıyafetlerde mavi ve yeşil de kullanılmıştır. Sadece bir tane erkek çocuğunun üstü kırmızı olarak yer almaktadır. Klasik anlamda renklerin cinsiyetçi şekilde sunumunu sadece kıyafetlerde değil sonraki kısımda ele alınacağı gibi dekorasyonda da görmekteyiz. 


\subsection{Anaokulunda renkler}

Cinsiyetçiliğin inşasında renk oldukça önemli bir unsurdur. Bu bağlamda ortak kültürün bir anlamda bilinçaltı haritalarını kız ve erkek çocuklarının kıyafetlerinde ve mekân kullanımındaki renklerde görebiliriz. Toplumsal sözleşmenin uzun süren somut gösterimleri olarak renklerin kullanılması sembolik bir aktarımı da sağlamaktadır (Sözen, 2003, s.11). Dolayısıyla bu aktarım aynı zamanda cinsiyetçiliği pekiştirici bir etki de göstermektedir. Kitapta yer alan renkler yukarıda çocukların kıyafetlerinde ve oyuncak ile oda renklerinde de aynı somut aktarımı beslemekte ve yeniden inşa edilmesine yardımcı olmaktadır. Genel anlamda renk ve cinsiyet ilişkisine bakacak olursak; yeşil, deniz mavisi, turuncu ve koyu mor renkler daha ziyade erkek dünyasını gösterirken; kadınlar daha çok yeşil, açık mavi, pembe (Sözen, 2003, s.67) gibi renklerle gösterilmektedir. Bu yazının ve çalışmanın alanı nedeniyle renk ve duyu psikolojisine detaylı bakılmayacaktır. Ancak çok kısaca kadınlar ve erkekler için belirlenmiş renklerin simgesel ve kültürel anlamda cinsiyetçiliği pekiştirdiğini de eklemek gerekmektedir. Erkek bebeklere mavi, kız bebeklere pembe renk giydirilmesinden başlayan süreç bu kitapta izleneceği üzere devam etmekte ve hem cinsiyetçilik pekiştirilmekte hem de yazarın kaleminden çıkan somut göstergeler üzerinden yeniden inşa edilmektedir. Bu bağlamda incelendiğinde erkekler kahverengi ve tonları, gri, siyah, yeşil, mavi tonlarında daha fazla yer alırken sadece bir örnekte bir erkek çocuğunun üstündeki kıyafet kırmızı renkte gösterilmiştir. Kızlar da mor, kırmızı, pembe ve benzer renklerde gösterilmiş ve bir tane kız çocuğunun elbisesi sadece açık mavi olarak resmedilmiştir.

Odalarda kız ve erkek çocuklar için ayrılan oda duvarları erkeklerde mavi, kızlarda pembe ağırlıklıdır. Yine erkeklerin oyun odalarındaki perde yeşil, kızlarınki kırmızıdır. Beden eğitimi dersinde gösterilen çocuklarda kızlar kırmızı ve mor spor kıyafetleri ile, erkekler ise beyaz, yeşil, kahverengi, siyah şeritli sarı renklerde gösterilmiştir.

Resim odası açık kahverenginde gösterilirken, dans edilen oda mor olarak gösterilmiştir.

Anaokulundaki bir başka mekân da lavabolardır. Burada da kızların havlusunda kırmızı, erkeklerde ise yeşil renk tercih edilmiştir. Havlunun asıldığı aparat erkeklerde mavi bir araba, kızlarda ise kırmızı bir elma ile resimlenmiştir. Buna ilave olarak kızların diş fırçaları için ayrılan kaplarda mor, kırmızı, pembe ağırlıklı iken erkeklerinkinde mavi, sarı ve yeşil hâkimdir.

Mutfak ise sarı renk ile dekore edilmiştir

Uyku odası yine mor duvarlar ile kırmızı perdelerle süslenmiştir.

\subsection{Anaokulunda oyuncaklar}

Erkekler araba ile oynamaktadır. Odanın bir tarafında yer alan rafın üzerinde ise sırasıyla çöp kamyonu, vinç, helikopter, motorbisiklet, trafik lambaları, gemi, araba, kaldıraç, tren yer almaktadır. Bu raftan aşağı doğru yine bir helikopter sarkıtıımıştır. Bir diğer ifade ile erkekler teknik işler konusunda oyuncaklarla başbaşa bırakılmış ve resmedilmiştir. Yine erkeklerin oyun oynadığı odadaki saatin etrafında da aksesuar olarak arabalar resmedilmiştir. Trafik lambaları ve vinç gibi yine benzer hâkim ideolojiyi destekleyen (erkekler fiziksel güç gerektiren ve teknik meselelerden anlayan canlılardır) oyuncaklar da raflarda yer almaktadır. Ayrıca oyun odasında bu araçların zorlu parkurlardan geçtiğini gösterir mekanizmalar da oluşturulmuştur. Yine odada bir adet futbol topu yer almaktadır.

Erkeklerin oyun oynadığı odada perdeler yeşil renkte ve pencere çerçevesi kare olarak tasarlanıyor. Ayrıca çerçevenin iki tarafından da perdeler sarkıyor ve sanki rüzgar onları 
dağıtmışçasına duruyor. Bu durum kızların odasında farklı tasarlandığı için özellikle vurgulanmıştır. Kare daha hatları belirgin ve keskindir. Oysa kızların odasında yer alan yuvarlak şekilde tasarlanan çerçeve ise daha yumuşak ve hatları esnektir. Dolayısıyla diğer tüm öğelerle birlikte bu çerçevelerin farklı şekillerde tasarlanması da hâkim ideolojiyi desteklemektedir. Ayrıca erkeklerin odaları mavi renkle boyanmış ve boyanın içinde araba firgürleri yerleştirilmiştir.

Kızların odalarında üst rafta; tava, kavanoz içinde küçük boncuklar, ayıcık, kaplumbağa, fil, kız bebekler, kız bebek yatağı ve içinde bir kız bebek, yine en son kısımda bir kız bebek resmedilmiş. Ayrıca raftan aşağı doğru kız bebek elbiseleri askıda asılı olarak yer almaktadır. Bir de bu raftan aşağı doğru kolye sarkıtılmıştır. Kızların odasında ayrıca üzeri kırmızı ile belirgin olan bir masa yer almaktadır. Masanın üzerinde bir tencere ve yanında bir fincanın içinde renkli kalemler yer almaktadır. Masanın çekmecelerinden bir tanesinden dışarı bir çorap sarkmaktadır. Kızların ellerinde kız bebekler, bebek arabaları ve koltukta oturan bebek vardır. Bir köşede bir kız çocuğu bu koltukta oturan bebeğe yemek yedirmektedir. Ayrıca yine bebek elbiseleri ile dolaşan kızlar gösterilmektedir. Bu odanın penceresi erkeklerinki gibi kare değil yuvarlak olarak tasarlanmıştır. Ayrıca perdeleri kırmızıdır. Buradaki perdeler erkeklerindeki gibi savruk değil, düzenli ve tek tarafta tutturulmuştur. Tavandan sarkan bir sepetin içinde kırmızı, sarı ve mor çiçekler yer almaktadır. Ayrıca bu odada yer alan raftan kaşık, spatula gibi eşyalar sarkıtılmıştır.

Odanın diğer köşesinde tavandan bir balon ve içinde şapkalı bir kız çocuğu sarkıtılmıştır. Duvar boyası pembe ve içinde küçük çiçekler resmedilmiştir.

Erkeklerin odalarında yer alan raf mavi ve kalın bir çizgi ile belirginleştirilirken kızlarınki kırmızı ile gösterilmiştir. Son olarak erkeklerin pencere pervazının altına da mavi bir şerit çekilmiştir.

\subsection{Anaokulunda öğretmenin durumu}

Öğretmen olarak gösterilen arı da elbise giyen ve saçlarını topuz yapmış bir kadın olarak resmedilmiştir. Tüm çocuklar spor kıyafetlerini giymiş olarak gösterilirken öğretmen elbisesi ile beden eğitimi dersine katılmıştır. Resim ve dans etkinliklerine de yine aynı kıyafetle devam etmiştir. Öğretmenin belki de en fazla aktif olabileceği ve cinsiyet ayrımcılığına karşı çıkabileceği yer olan oyun odasındaki hali ise tamamen pasiftir. Sadece sandalyede oturarak çocukların oyunlarını izleyen öğretmen olaylara müdahale etmeyerek bir anlamda bu ayrımı pekiştirmiştir. Mekân olarak anaokulunun tüm kurgusu cinsiyetçiliği yeniden inşa ediyor olsa da öğretmenin sessizliği ayrıca bu ayrımı pekiştirmektedir.

\section{DEĞERLENDIRME VE SONUÇ}

Yapı Kredi Yayınları tarafından yayınlanan, okul öncesi çocuklar tarafından okunan ve çoğu kütüphanede yer alan Uğurböceği Sevecen ve Salyangoz Tomurcuk Anaokulunda kitabı cinsiyetçiliğin anaokulunda nasıl yeniden inşa edildiğini net bir şekilde göstermektedir. Kullanılan renklerde kızların genel hatları ile kırmızı, mor ve tonları ile erkeklerin ise mavi, yeşil, gri ve kahve tonlarında resmedilmesi kadar ayrı odaların perdelerinin de buna uygun renklerde olması göze çarpmaktadır. Yani yeşil erkek perdesi yanında kare çerçeve ve kırmızı perde yanında yuvarlak çerçeve ile kadın ve erkeğe ait olan kodlar daha da belirginleştirilmektedir. Buna paralel oyuncakların cinsiyetçi şekilde ayrıştırılması ve çocukların bu kurgusal dünyaya yönlendirilmeleri de çok açıktır. En başta belirtilmesi gereken nokta ise kız ve erkek serbest zaman veya oyun oynayacakları mekânların cinsiyetlendirilmesi ve diğer tüm unsurların bu pekiştirmeye eşlik etmesidir. Otorite olarak kabul edilen öğretmenin pasif kalıp eril iktidarın söylemini tartışmaya açmaması da ayrıca 
ortak kabule işaret etmektedir. Tomurcuk kızların dünyasına kabul şartı olarak cinsiyetlendirilmiş ve kızlara ait olarak belirtilmiş bebekle yer alırken onlar için işaretlenen kalıpları daha da belirginleştirmektedir. Kadınlardan beklenen çocuk yapmaları, anne olmaları, saçlarının uzun olması ve elbise giymeleridir. Eril iktidarın kendilerine belirlediği tüm roller mekan üzerinden ve resimler eşliğinde okulöncesi çocuklara sunulmakta ve cinsiyetçilik yeniden inşa edilmektedir. Dolayısıyla kitaba dair yapılan analiz ile de mekanın cinsiyetçiliğin inşasındaki payı açıkça görülmektedir. Kitabın Türkçeye çevrilmesi dolaşım ağının geniş olduğunu da göstermektedir. Dolayısıyla basılı materyaller, işaret ettikleri mesajlarla farklı mekanlarda yeniden hedef kitlesine ulaşmakta ve bu da cinsiyetçiliğin farklı zamanlarda olsa da benzer hedef kitle nezdinde yeniden inşa edildiğini söylememize olanak tanımaktadır.

\section{KAYNAKLAR}

A. Mackinnon, Catharine, Feminist Bir Devlet Kuramına Doğru, (Çev.: Türkan Yöney-Sabir Yücesoy), Metis Yayınları, İstanbul, 2003.

Alkan, Ayten, Yerel Yönetimler ve Cinsiyet, Dipnot Yayınları, Ankara, 2005.

Bhasin, Kamla, Toplumsal Cinsiyet, (Çev.: Kader Ay), Kadav Yayınları, İstanbul, 2003.

Delaney, Carol, Tohum ve Toprak, (Ed.: Asena Günal), İletişim Yayınları, İstanbul, 2012.

Bora, Aksu, "Kamusal Alan Sahiden "Kamusal mı?", Kamusal Alan, (Ed.: Meral Özbek, Hil Yayınları, İstanbul, 2004.

Bora, Aksu, Yerel Yönetimler ve Cinsiyet, Dipnot Yayınları, Ankara, 2005.

Bora, Aksu, Kadınların Sınıfı, İletişim Yayınları, İstanbul, 2010.

Butler, Judith, Cinsiyet Belası \& Feminizm ve Kimliğin Alt Üst Edilmesi, (Çev.: Başak Ertür), Metis Yayınları, İstanbul, 2008.

Çakır, Serpil, "Osmanlı'da Kadınların Mekânı, Sınırlar ve İhlaller", Cins Cins Mekân. (Der.: Ayten Alkan), Varlık Yayınları, İstanbul, 2009.

Donovan, Josephine, Feminist Teori, (Çev.: Bora Aksu, Gevrek Ağduk Meltem, Sayılan Fevziye), İletişim Yayınları, İstanbul, 2007.

Gatens, Moira, "Twenty Years since "A Critique of the Sex/Gender Distinction": a Conversation with Moria Gatens", (Röp.: Mary Walsh), Australian Feminist Studies, Vol.19, No. 44, 2004, s. 213-223.

Kandiyoti, Deniz, "Türkiye'de Toplumsal Cinsiyet ve Kadın Çalışmaları: Gelecek İçin Geçmişe Bakış", Birkaç Arpa Boyu, (Der.: Serpil Sancar), Koç Üniversitesi Yayınları, İstanbul, 2011.

Köker, Eser (2004), "Saklı Konuşmalar”, Kamusal Alan, (Ed.: Meral Özbek), a.g.e., s. 543.

Özyeğin, Gül, "Kadınların Sınıfı Önsözü”, Kadınların Sınıfı, (Yaz. Aksu Bora), İletişim Yayınları, İstanbul, 2010.

R. Cuthbert, Alexander, The Form Of Cities, Political Economy and Urban Design, Blackwell Publishing, USA, 2006. 
Redfern, Catherine ve Aune, Kristin, Baş Harfi F, (Çev.: Aksu Bora, Simten Çoşar), Ayizi Kitap, Ankara, 2012.

Sözen, Mustafa, Sinemada Renk, Detay Yayıncılık, Ankara, 2003

Steeves, H. Leslie, "Feminist Teoriler ve Medya Çalışmaları", Medya, İktidar, İdeoloji, (Der. ve Çev.: Mehmet Küçük), Ark Yayınları, Ankara, 1999.

Simone, Beauvoir de, Kadın “íkinci Cins” Bağımsızlığa Doğru, (Çev.: Bertan Onaran), Payel Yayınevi, , İstanbul, 1993.

Tekeli, Şirin, 1980’ler Türkiyesi'nde Kadınlar, İletişim Yayınları, İstanbul, 2010.

Temürkan, Yıldız, "Kente Cinsiyetlendirilmiş Bir Mercekten Bakış", Kent ve Mekanda Cinsiyetçilik, (Haz.: Y. Yeşim Uysal), TMMOB Mimarlar Odası Ankara Şubesi Bülteni, Sayı: 87, Pelin Ofset, Ankara, 2011.

Townsend, Paula, "Gendered Space?", http://research.ncl.a.uk/forum/v3i1/gendered\%20space.pdf Erişim Tarihi: 14 Aralık 2016, Saat : 19.30

W. Scott, Joan, Toplumsal Cinsiyet: Faydalı Bir Tarihsel Analiz Kategorisi, (Çev.: Aykut Tunç Kılıç), Agora Kitaplığı, İstanbul, 2007.

Walters, Margaret, Feminism A Very Short Introduction, Oxford University Press, United States, 2005.

Yuval-Davis, Nira, Cinsiyet ve Millet, (Çev.: Ayşin Bektaş), İletişim Yayınları, İstanbul, 2003. 